\title{
Did the Pietists Become Esotericists When They Read the Works of Jacob Boehme?
}

\begin{abstract}
A S is commonly known, Jacob Boehme (1575-1624) is, and has been ever since his emergence, difficult to place in the history of thought. The historian Preserved Smith, for instance, characterized him as 'the most religious of philosophers' (Smith 1962: 171). As such Boehme could be seen to be on a borderline somewhere between philosophy and theology. From a reverse point of view, however, he could also be termed the most speculative of the religiously minded, as a deeply religious thinker or mystic. His influence is also shown in both fields; not only was he to play an important role within German philosophy during the Romantic era, but also, within the Pietist movement, or the movement for revival of piety within the Lutheran church. Focusing on the Pietist movement, initiated by Philipp Jakob Spener (1635-1705) in the late seventeenth century and its spread on Finnish ground, I will show that where Boehmian influence is traceable, it reached quite different environments depending on the movement's leaders or followers. My intention is also to shed some light on the controversy between Lutheran orthodoxy and Pietism in early eighteenth century Finland.

One way to understand the apparent heterogeneity of Boehmian influence is to see Boehme himself as an exponent of not one single tradition, but-as Andrew Weeks has described him-as the great Baroque synthesizer, fusing many different lines of thought:
\end{abstract}

[A] surprising number of the themes of German mysticism are reassembled and synthesized in his oeuvre: Hildegard's epic struggle between the forces of good and evil... ; Eckhart's reflective knowledge which knows God in self-knowledge; Seuse's chivalrous devotion to Lady Wisdom; Tauler's use of parabolic symbols; the Christian Kabbalah and Hermetism of the Renaissance. . . ; the Spiritualist's defence of freedom and toleration. .. (Weeks 1993: 171-2.)

And so on. There are, moreover, Gnostic and Neoplatonic elements to be found in him, as well as traits from the tradition of Gregory of Nyssa 
and Erigena. More obvious influences are, of course, the strong Lutheran and Paracelsian elements in his thinking (Weeks 1993: 172).

During recent decades Boehme has received most attention from the field of the study of esotericism. This has rendered him as being in something of a position as one of the major exponents of a tradition, or a family of traditions, that sets out to reveal the hidden depths and mysteries of Man and Nature.

The difficulty in labelling Boehme is encountered here, too. In the broad context of esotericism he is first and foremost described as a theosophist, and as such, and due to the major impact of Germanic Naturphilosophie within Western esotericism, even as the 'prince of western esotericism' (Faivre 1994: 64). A more conventional classification is to place him within the tradition of German mysticism, which is what Weeks does. As to the label Hermetist, we find, for instance, that Ingrid Merkel, in her study of Hermetic imagery in the work of Jakob Böhme, states that it is 'with caution and reservation' that she 'introduce Jacob Boehme into the circle of Hermetists' (Merkel 1988: 302). In Glenn Alexander Magee's Hegel and the Hermetic tradition Boehme is, however, described as the foremost exponent of the hermetic tradition leading up to Hegel (Magee 2001: 36-50). Still another example could be taken from Cyril O'Regan's Gnostic Apocalypse (2002), which argues that Boehme should be seen as the person mainly responsible for, or a prime mover in, a return of ancient Gnosis in early modernity. The Russian philosopher Nicolas Berdyaev also regards him as 'one of the greatest of Christian Gnostics', but, as he maintains, 'not in the sense of the heresies of the opening centuries of the Christian era' (Berdyaev 1958: v).

This has, of course, to do with various approaches or perspectives, as well as how we define the concepts at hand. As is well known, these concepts also overlap each other in many ways. Placing Boehme on the map of religious thinking in Finland will not, I am afraid, make any definitions clearer. It will, on the contrary, perhaps only further underline the elusiveness of Boehmian thought and religious philosophy.

\section{Boehmenist Influences in Finland}

In the standard, and still largest, documentary collection of religious movements in Finland, covering a period from late seventeenth to the early nineteenth centuries, the publisher Matthias Akiander dedicates no less than two thirds of his Preface to present the tenets of Jacob Boehme. The reason he gives might sound provocative indeed: 'Among the many 
doctrinal parties', Akiander writes, 'which will be shed light on by primary sources, the school of Böhme with its corollaries deserves special attention in our country, because its doctrines first gained ground here, has been preserved for the longest time and of all the sects has most infiltrated the religious ideas of other doctrinal parties' (Akiander 1857, I: vi). ${ }^{1}$

A widespread reading and influence of Boehme is also documented elsewhere. According to the classic, and still unsurpassed study of Pietism of 1911, by the church historian Emanuel Linderholm, Boehmian thinking was, in at least some regions, actually to pose a real threat to orthodox Lutheranism at the end of the seventeenth century. Boehmian theosophy became at the time strongly promoted through the works of Fr. Brechling and J. G. Gichtel and the latter's editing of the writings of Boehme in 1682. From 1690 onward, the influence reached new heights through the English Behmenists John Pordage, Thomas Bromley and Jane Lead. It is important also to view this influence against a wider intellectual and dissident background, comprising Quakers, Mennonites, and Schwenkfelders, who shared the basic concepts of religion as an 'inner' activity, in terms of 'word', 'light' or 'man'. The notion of religion as something primarily internal and private, especially in terms of an 'inner word', became, according to Linderholm, for late seventeenth century people, what ideas of progress were to become for a later age (Linderholm 1911: 39-40).

\section{Early Radical Pietists}

The earliest documented influence of Boehmian ideas in Finland can be traced to the turn of the eighteenth century among the first radical Pietists, Lars (Laurentius) Ulstadius (d. 1732) and Peter Schäfer (16621729). Although they were not Boehmenists in the strict sense of the word, influenced as well by other thinkers as they were, they stand out, however, as preparers of the particular milieu that later was to cultivate a spread of Boehmenism. In a new edition of J. N. Edenius's church history Epitome Historiae ecclesiasticae novi Testamenti from 1708, the bishop

1 'Bland de flera läropartier, som nu komma att med urkunder belysas, förtjänar Böhmes skola med dess utgreningar en särskild uppmärksamhet i vårt land, emedan dess läror tidigast vunnit insteg hos oss, längsta tiden bibehållit sig och mest av alla sekter inmängt sig i de öfriga läropartiernas religiösa föreställningar.' 
in Turku (Swe. Åbo) Johan Gezelius Jr (1647-1718) appended an account of radical Pietism in the form of two distinct movements, one that used Schwenkfeldian, Weigelian and Labadistic doctrines, the other consisting of the followers of Boehme (Råberg 1893: 128-30). Both Ulstadius and Schäfer would belong mainly to this first category and Gezelius probably, in updating the work with the new heresies, also had these two in his mind. With Ulstadius we actually, as it were, witness one of the earliest appearances of radical Pietism within Lutheranism. After reading Schwenckfeld and Weigel, among others, he had resigned from his duty as minister in his hometown Oulu (Swe. Uleåborg) and travelled to Turku in 1683, where he caused a great stir by interrupting a sermon in Turku Cathedral in 1688; an incident for which he was sentenced to death in 1692, though the sentence was overturned into life imprisonment. As his friend and pupil, Schäfer was soon afterwards, and under heavy pressure, forced to cancel his conviction. These early events seem to have put an abrupt end at the very beginning to the spread of dissenting ideas (Linderholm 1911: 82-6).

The harsh treatment by the Lutheran orthodox clergy had, however, more of a reverse effect, an outcome that subsequently was to raise Ulstadius and Schäfer to something of martyrs for dissenters still to come. The case of Schäfer is particularly enlightening. Esteeming his situation as excruciating he left the country and spent more than ten years of restless living abroad. During his peregrinations he met Spener in Berlin and worked as a teacher at August Hermann Francke's home in Halle. From Halle he moved on to Quedlinburg in 1699 to reside at the place of Gottfried Arnold. Arnold was at the time deeply immersed in studying Boehme and particularly his doctrine of the Heavenly Sophia, which resulted in the work Geheimnis der Göttlichen Sophia next year. (Laine 2006: 202.) More importantly, Schäfer recalled to Arnold the events and the persecution he and Ulstadius had suffered in Finland, which Arnold included in his Unparteyische Ketzer- und Kirchenhistorien published 1699-1700. In Holland Schäfer established contacts with mystics and theosophists such as Gichtel, who mentions him in his Theosophia practica from 1732. Schäfer's stay in Holland and notably his acquaintance with Quakers finally encouraged him to travel to Pennsylvania, where he met William Penn, with whom he continued to correspond after his return to Finland.

Returning to Finland in 1701, and deeply regretting his former repeal of religious conviction, he subsequently stepped forward as an apocalyptic preacher from the year 1707 onward, recapitulating the criticism Ulstadius had directed against the clergy 20 years earlier. Schäfer simi- 
larly received a death sentence, which was altered to life imprisonment in 1709, and was locked up in Turku Castle, from where he was transferred to the Castle of Gävle in 1714 (Akiander 1857, I: 8-22).

During his imprisonment Schäfer gained a reputation as an apocalyptic and visionary that was to influence even the Royal Family, as he identified King Carl XII as Der Löve aus der Mitternacht; the yellow lion that was to appear in anticipation of the final end. In his captivity Schäfer studied, among other works, the writings of Boehme, which-as can be noticed from his diaries-were particularly dear to him. Among the people who supported him from abroad, Arnold's pupil Johann Konrad Dippel might be mentioned, who in 1712 through their mutual friend Johan Andersson Dorsche, expressed his concern for Schäfer's welfare and collected a sum of money to be sent to him (Ruuth 1915: 21).

\section{The Eriksson Brothers}

In the late 1730s, a new movement began to emerge around the brothers Jacob (1689-1737) and Erik Eriksson (1695-1761). Natives of Kälviä (Swe. Kelviå) in central Ostrobothnia, there seem to be no direct ties connecting them to the events in Turku, but they came to regard themselves as heirs to both Ulstadius and Schäfer (Loimaranta 1940: 304-5). Their religious and philosophical orientation was more clearly that of Jacob Boehme, whose writings they first might have come across during their periods of service in the Carolingian army (Loimaranta 1940: 292-3).

With the Eriksson movement, a parallel to the Philadelphian society can be seen emerging on Finnish ground. In its approach and particular mode it was, however, quite different, as it lacked almost completely that group's characteristic visions and expectations, as to its charismatic leader Jane Lead. Due to external pressures, the Finnish movement developed into a highly exclusive and uncompromising group of dissenters, displaying intolerance both towards the clergy and other religious approaches. In their view, any attempts to compromise with orthodox views were detestable. In addition to the works of Boehme, they accepted only a few other writings, such as Thomas Bromley's Way to the Sabbath of Rest, Pordage's Göttliche und Wahre Metaphysica and works by Gottfried Arnold. The writings of Jane Lead were only to be read with great caution (Loimaranta 1940: 289).

The presence and influence of the brothers was deemed so dangerous that they were expelled from the country in 1734, and became, as it were, the first to be forced to leave on religious grounds. With a group 
consisting of 85 followers they travelled via Stockholm and Copenhagen to Holland and Germany, where they impatiently moved from one place to another, tormented by both external and internal conflicts. From the viewpoint of church orthodoxy they were indeed dangerous, as their presence usually promoted an immediate radicalization among societies of moderate Pietists. Returning in 1745 to Sweden, the group had reduced to 21 in number, with Erik as the sole leader, as the older brother Jacob had died in 1737. They finally found a haven in Skevik in Sweden where the movement survived up to the middle of the nineteenth century when the last follower passed away (Janzon 1866).

\section{The Mystics of Ostrobothnia}

The spread of Boehmian ideas also gave birth to a loosely structured movement known as the 'Mystics of Ostrobothnia'. The movement undoubtedly had its prelude in the earlier events, although so far no direct influences have been documented. Moreover, the group was quite different both in nature and religious outlook from the preceding ones. Their leader Anders Collin (1754-1830) was a renowned librarian and Boehmenist in Stockholm, who held a lively correspondence with his followers overseas in Ostrobothnia. What is remarkable about this movement is the number of Finnish translations of works by Boehme they produced. Whereas the Eriksson brothers did not translate any writings by the Silurian shoemaker, the 'mystics' produced a number of books, chapters and shorter works in the form of handwritten manuscripts, which circulated among the followers. In addition to the works of Boehme, they also produced translations of other works, even nonreligious writings, such as books on history and geography (Grönroos 1972). Although the Mystics of Ostrobothnia widely read the works of Boehme, they had, as can be seen from the translations, quite a different approach to the theosophical corpus than was the case with the Eriksson brothers. Aurora and other more obscure works were not translated but merely the explicit devotional writings focusing on Christian life. The Boehmenist literature seems for them, therefore, to have served first and foremost as devotional literature. In contrast to the Erikssons' movement, Collin was cautious also to remind his followers not to depart from the Lutheran church (Pajula 1911: 6, 11; Kvist 1997: 123-6). This made the actual extent of the movement more difficult to detect, and its influence, accordingly, can be traced well into the mid-nineteenth century. 


\section{Wallenbergianism}

Owing to the dispersal of writings by Boehme still another movement emerged before the end of the eighteenth century. In Lapua (Swe. Lappo) in southern Ostrobothnia, a translation of Boehme's Psychologia vera had come into the hands of Jacob Wallenberg, a glass manufacturer who had fallen into misfortune when planning to establish a glass factory. In 1798 he became the charismatic leader and prophet of a group in the neighbouring district of Kauhava, an event that caught attention early on due to its exceptional activities. Wallenberg, who evidently held a strong appeal for women, came to initiate a series of rituals including also some apparently sexual ingredients. More than Boehmian teachings proper, joint rites in the form of 'jumping' and 'trampling' seem to have been important for the group's constancy. By jumping, one trampled on the snake's head by which action the adherents were carried into higher bliss. Anther important ingredient was the abundant consumption of alcohol and tobacco, which was believed to keep the devil away. During the meetings all sexual restrictions were abandoned in favour of heavenly marriages, which were to be carried out in their carnal sense. The atmosphere of sexual relief and freedom that Wallenberg fostered held, not surprisingly, a particular appeal for the youth. Although only a few were vouchsafed to behold the inner secrets of his teaching, the following numbered roughly one hundred people (Akiander 1860, IV: 15 ff.).

The suspicious activities of Wallenberg must have resulted in still greater wariness from the clergy when it came to his prophetic role. Abandoning both communion and service, he claimed that Luther had falsified the teachings of the apostles. Furthermore, God had become disappointed with Jesus and overturned his mandate and, accordingly, replaced him by Wallenberg, whose mission was nothing less than to redeem the whole of humanity. In his new position, Wallenberg was also capable of miracles, as for instance turning stones into gold-this secret, however, he failed to prove to his followers (Akiander 1860, IV: 22-6).

Wallenberg was subsequently arrested and like Schäfer and Ulstadius before him, given a death sentence, which was overturned to life imprisonment. Wallenberg died shortly after his arrest, but the movement persisted, and Psychologia vera continued to be read as the 'Book of Boehme' (Böhmin kirja) or 'Catechism of Wallenberg'. In the early nineteenth century the group moved to the adjacent district of Kuortane and became known as the 'Wasuits' after its new leader Isak Wasumäki (1783-1854). The movement was still alive at the time of Akiander's collecting of documentary sources in 1860 . He noted that of the inhabitants 
of Kuortane at the time, approximately one fourth of the elderly population were attached to the movement (Akiander 1860, IV: 38). After Wasumäki's death and under the leadership of Enoch Hynnilä some decline was reported regarding proselytizing new followers. Still, however, in the early twentieth century a priest, Kustaa Hallio, reported that Boehmenist literature continued to be read in a number of districts in Ostrobothnia (Hallio 1901: 350).

The spread of Boehmian theosophy in the area of Ostrobothnia in Finland had its repercussions among the upper and middle class cultures as well. An instructive example is Christian Henrik Snellman (1777-1855), father of the Finnish national philosopher Johan Vilhelm Snellman, who developed an intricate spiritual philosophy on the basis of Emanuel Swedenborg and also, to some degree, the views of Boehme. After the death of his first wife, the mother of Johan Vilhelm, he married Catharina Sofia Ahla (1798-1879) who was a devout follower of Boehme. Living in Alahärmä in Ostrobothnia, Christian Henrik expressed a deepest respect for Catharina as to her religious and philosophical views. In 1835 he wrote to his son that she is 'the greatest philosopher who gets everything gratis through faith; [i.e.] everything that so called science with its logical metaphysical reasoning produces [and] what Schelling, indeed, has tried' (cited in Manninen 1995: 232). ${ }^{2}$ Schelling's debt to Boehme is well known, but what is more interesting in this context, is that the followers of Boehme indeed could affiliate and correlate their views with the new Zeitgeist, the philosophy of the Romantic Movement. This includes the system of Hegel (Magee 2001; Merkel 1988: 309) as well, which was to capture the mind of J. V. Snellman and establish Hegelianism as the national philosophy of Finland. A renewed esteem of the doctrines of Boehme emerged to some degree also through the mediation of Franz von Baader, whose direct influence, though, seems to have been restricted to the mediating theology of A. F. Granfelt (1815-92) (Luukkanen 1993).

2 'Mamma [är] den största filosoph, som får alt gratis genom Tron; alt hvad så kallad Wettenskap kan med sin Logiskt Methafysiska slutkonst, utkläcka som Schelling nog försökt.' 


\section{Conclusions}

Due to the divergent character of the reception of Boehme's ideas in Finland, as roughly drafted above, it would clearly be inappropriate to approach Finnish Boehmenism as one particular or distinctive tradition. If we, notwithstanding, search for something that could be termed esoteric, it would be the particular form of secrecy that was shared and upheld by the Erikssons, the mystics, as well as the movement of Wallenberg. As such, it was a precaution and protection against the church authorities, for the reason that they owned, read and contemplated books that were marked as heretical. Another dimension of esotericism could be, pertaining to the Erikssons particularly, that they carefully selected their followers and approved only those whom they saw fit for further instruction or teaching. With the Erikssons and with the mystics of Ostrobothnia, the central issue was the guidance into a deeper inner life, while the core within the Wallenberg group was an initiation to become close to the saviour himself, and to be one of the chosen at the imminent arrival of the new millennium. Whereas the Erikssons' movement was characterized by gravity and seriousness, the Wallenbergians and Wasuits were more explicitly a religion of frivolousness and joy, or to be in an 'easy spirit of the Lord' (helpossa Herran hengessä) (Akiander 1860, IV: 36). The inner, secret life (salattu elämä) of the Wallenberg movement was not a withdrawal to an introspective, private life, or an abandonment of personal will, but simply a matter of hiding the group's activities of drinking, dancing and sexual intercourse. For them, living without boundaries and restrictions and in an 'easy spirit', was a truly Christian way of life.

Wallenberg, as well as the early radical pietist Peter Schäfer, were clearly not disposed to the religious philosophy of Boehme in the sense that the two brothers Eriksson and their followers had been. Notwithstanding, there was a strong kinship, as when Erik Eriksson declared that there were no 'real priests' in the country, though if Schäfer were still alive, he alone could give an accurate sermon (Akiander 1860, IV:321). As with the early radical dissenters, Wallenberg's movement was part of a wider apocalyptic and chiliastic tradition. Although the writings of Boehme had functioned mainly as consolation for Schäfer during his lifetime imprisonment, it is in his, as well as the Wallenbergians', chiliastic vision something vitally Boehmenist inspired can be detected. The expectation of the approaching millennium was for them the promise of a new regenerated earth which had a markedly alchemical flavour, i.e. a golden age where everything was to be 'tinctured' to its highest de- 
gree of being (Akiander 1857, I: 30 and 1860, IV: 18). Perceiving nature thus 'alchemically', was to perceive the world as a dynamic process in terms of a perpetual battle of opposing elements. The world, for them, was not a static order where a mere confession for the sake of salvation would do; it was, more accurately, a dynamic order of becoming and a dialectical process that Berdyaev has pointed to,- -as regards its immense importance to German Idealism-namely 'that a thing can be revealed only through another thing that resists it. Light cannot reveal itself without darkness, nor good without evil, nor the spirit without the resistance of matter' (Berdyaev 1958: xi).

In a certain sense Boehmenist theosophy is, altogether, a deep realism, in grasping a certain feeling for being. This philosophical underpinning has usually not received attention in relation to the Pietistic movement. Because God, for them, was ultimately will and not rationality, it followed, feasibly, that all theologies in the sense of doctrinal creeds were misdirected in their very foundations. The basis of the Kingdom of God was not in words but in power; their religion was, consequently, a Christianity of power (voima-christillisyys) (Akiander 1858, II: 29). In another sense, the Boehmenists could also be seen as early psychologists, as they were occupied with reading the personal book, or to withdraw into the inner life and strife between good and evil. Since Boehme's God was-as Pastor Richter reported early on-made of sulphur and mercury, the world was primarily, and through God's self-realization, a psychic process. Boehmenism could consequently offer, as it were, an ontological foundation of its own or an orientation that provided stability beyond theological disputes.

\section{References}

\section{Akiander, Matthias}

1857-63 Historiska upplysningar om religiösa rörelserna $i$ Finland $i$ äldre och senare tider I-VII. Helsingfors.

\section{Berdyaev, Nicolas}

1958 Unground and Freedom. In: Jacob Boehme, Six Theosophic Points and Other Writings. With an Introductory Essay "Unground and Freedom" by Nicolas Berdyaev; pp. v-xxxvii. Ann Arbor: The University of Michigan Press.

\section{Faivre, Antoine}

1994 Access to Western Esotericism. Albany: State University of New York Press. 


\section{Grönroos, Henrik}

1972 Geografiat ja reisu-kirjat. Bibliophilos 2: 3-13.

\section{Hallio, Kustaa}

1901 Suomen mystikoista. In: Teologisk Tidskrift - Teologinen aikakauskirja 1901: 345-56, 401-9.

\section{Janzon, G.}

1866 Bidrag till Skevikarnas historia. Örebro: Lindh.

\section{Kvist, Hans-Olof}

1997 Der Einfluss Jakob Böhmes in Finnland. In: Klaus Fitschen \& Reinhart Staats (eds), Grundbegriffe christlicher Ästhetik. Beiträge des V. MakariosSymposiums Preetz 1995; pp. 119-39. Wiesbaden: Harrassowitz Verlag.

\section{Laine, Esko M.}

2006 Taivaallinen Sofia ja lihallinen Eeva. Seksuaalisuus suomalaisessa radikaalipietismissä ennen isoavihaa. In: Minna Ahola, Marjo-Riitta Antikainen \& Päivi Salmesvuori (eds), Taivaallista seksiä. Kristinusko ja seksuaalisuus; pp. 189-208. Helsinki: Tammi.

\section{Linderholm, Emanuel}

1911 Sven Rosén och hans insats i frihetstidens radikala pietism. Uppsala: Almqvist \& Wiksell.

\section{Loimaranta, Sakari}

1940 Erikssonien mystillis-separatistinen liike vuoteen 1745. Lahti.

\section{Luukkanen, Tarja-Liisa}

1993 In Quest of Certainty. Axel Fredrik Granfelt's theological epistemology. Helsinki: Luther-Agricola-Gesellschaft. (Schriften der Luther-Agricola-Gesellschaft, 29)

\section{Magee, Glenn Alexander}

2001 Hegel and the Hermetic Tradition. Ithaca \& London: Cornell University Press.

\section{Manninen, Juha}

1995 Härmä-katekesen. Christian Henrik Snellmans (1777-1855) swedenborgiansk-mystiska världsbild. In: M. Lahtinen (ed.), Historiallinen Arkisto 105; pp. 179-250. Helsinki: Suomen Historiallinen Seura.

\section{Merkel, Ingrid}

1988 Aurora; or, The Rising Sun of Allegory: Hermetic Imagery in the Work of Jakob Böhme. In: Ingrid Merkel \& Allen G. Debus (eds), Hermeticism and the Renaissance: Intellectual History and the Occult in Early Modern Europe; pp. 302-10. Washington: The Folger Shakespeare Library.

\section{O'Regan, Cyril}

2002 Gnostic Apocalypse: Jacob Boehme's Haunted Narrative. Albany: State University of New York Press.

Pajula, J. S.

1911 Jacob Böhmen vaikutuksesta Suomen n. k. mystikoihin. Teologisk Tidskrift - Teologinen aikakauskirja 1911: 1-12. 


\section{Råberg, Herman}

1893 Teologins historia vid Åbo universitet I. Helsingfors: Svenska Litteratursällskapet. (Skrifter utgivna av Svenska Litteratursällskapet i Finland, 23)

\section{Ruuth, Martti}

1915 Kaksi Petter Schäferin päiväkirjaa osaksi lyhennettyinä sekä johdannolla, muistutuksilla ja nimiluetteloilla varustettuina. Helsinki: Suomen kirkkohistoriallinen seura. (Suomen kirkkohistoriallisen seuran toimituksia XII,1)

\section{Smith, Preserved}

1962 Origins of Modern Culture 1543-1687. New York: Collier Books.

Weeks, Andrew

1993 German Mysticism from Hildegard of Bingen to Ludwig Wittgenstein: A Literary and Intellectual History. Albany: State University of New York Press. 